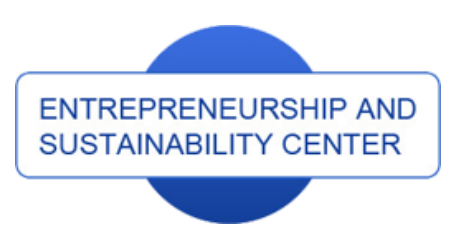

Publisher

http://jssidoi.org/esc/home
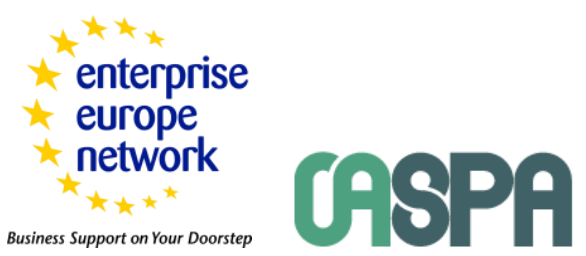

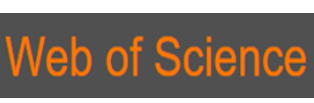

1) Clarivate

\title{
TEAMWORK MANAGEMENT IN CREATIVE INDUSTRIES: FACTORS INFLUENCING PRODUCTIVITY
}

\author{
Jurate Cerneviciute ${ }^{1}$, Rolandas Strazdas ${ }^{2}$ \\ ${ }^{1}$ Vilnius Academy of Arts, Maironio St.6, LT-01124 Vilnius, Lithuania \\ ${ }^{2}$ Vilnius Gediminas Technical University, Pylimo St.26/1, LT-01132 Vilnius, Lithuania \\ E-mails.'1 jurate.cerneviciute@vda.lt; ${ }^{2}$ rolandas.strazdas@vgtu.lt
}

Received 20 June 2018; accepted 20 November 2018; published 30 December 2018

\begin{abstract}
The 'experience' economy, characterizes by the growing needs for cultural identity and social empowerment, and aided by technologies of knowledge generation, information processing and communication of symbols, further reinforce this. The creative industries involve the concretization of an image, through whatever medium for some form of economic return. However, the nature of experience goods makes demand pattern unpredictable and production process difficult to control. The uncertainty of demand for the creative product, pose managerial and organizational challenges. The structure and staffing of creative projects are often temporary, as are capital investment. Success is dependent on the composition of projects teams with individuals and groups working in a highly interactive and adaptive fashioning of the product: Despite this fact, a great deal of research conducted in the area of group dynamics suggests that groups are often much less creative and productive than they are usually assumed. The important question of how to manage creative teams to achieve a high productivity with limited resources and time arises in innovation management both from the theoretical and practical points of view. There is still no clarity which factors affecting productivity of teamwork are more important than others. The study was aimed at the identification most important factors for the productivity of teamwork. The survey of 113 student creative teams in 8 counties (Lithuania, Poland, Canada, China, France, Italy, Russia, and Denmark) was performed. Based of the findings the hierarchy of the significance of the factors influencing the productivity of teamwork is established and described in the article.
\end{abstract}

Keywords: collective creativity; teamwork; efficiency in creativity; creative industries

Reference to this paper should be made as follows: Černevičiūtė, J.; Strazdas R 2018. Teamwork management in Creative industries: factors influencing productivity, Entrepreneurship and Sustainability Issues 6(2): 503-516. http://doi.org/10.9770/jesi.2018.6.2(3)

JEL Classifications: D21, O31, O10, O32

\section{Introduction}

The 'experience' economy, characterizes by the growing needs for cultural identity and social empowerment, and aided by technologies of knowledge generation, information processing and communication of symbols, further reinforce this (Stepaniuk 2018; Strielkowski 2018). The term 'creative industries' reflect the progression of 
symbolic creativity being organized around, and for, the market: the industrialization of culture and its commodification for the mass audience (Hesmondhalgh 2007; Mitkus, Maditinos, 2017).

The creative industries involve the concretization of an image, through whatever medium for some form of economic return. However, the nature of experience goods makes demand pattern unpredictable and production process difficult to control. The uncertainty of demand for the creative product, pose managerial and organizational challenges. The structure and staffing of creative projects are often temporary, as are capital investment (DeFillippi, Arthur 1998). Success is dependent on the composition of projects teams with individuals and groups working in a highly interactive and adaptive fashioning of the product: the necessary skills for a film project are specialized into narrow creative, technical, and managerial realms that they are held by individual experts: creatives (writers, designers, choreographers, actors, directors), technicians (editors, cinematographers, lighting technicians) and managers (producers, line producers, controllers, accountants, financiers, and marketers), working concurrently and successively on a film (Wasko, 2003; Eliashberg et al, 2006). A film project is typically set up and controlled by a production company where the producers, marketers, and sometimes the financiers, are long-term employed.

Creative industries and creative-based organisations need to cope with challenges whether and how to control of the creative process; how should be mediated relationship between producer and consumer. Organizational practice exemplified by the creative industries emphasizes coping with problems, managing in states of uncertainty and unknowability, and thus challenges traditional thinking on managing people, production and marketing to the consumer. The challenge for managers and policymakers is to choose the most efficient organization in order to profit from the creativity - in the case of creative industries, the key problem is how firms, labour markets, and industries are built around the raw material constituted by "creatives", i.e., individuals with cultural (as well as technical) skills.

The creative act is an act of managing self, managing others and managing objects. It is the activity of organizing, co-ordinating and directing. Success in both areas often involve collaborative practice, especially as the basis for innovation. Although emanating from different sources, there are pressures to innovate in both management and art. The artist is obliged to innovate from that which went before in order to claim an individual voice. Within business, innovation of product or process is equally a form of 'market' imperative. Both may be seen as a form of practice. While this is largely recognized for the artist, the manager does not often see him as so engaged. A process of reflection 'what it is that they do' and 'how they do what they do' is not traditionally part of a recognized discourse of management activity. The introspective nature of the artistic process as the individual 'struggles' in order to express a creative intent might on first glance place it well outside the norms of management activity.

A greater awareness of management as practice opens up discussion as to the importance of skill and craft in the practice. Breaking from the traditional view of management as a role, or the the disciplinary of industry, management as practice and the need for reflexivity and self-critique in achieving good performance have been emphasized (Gabriel 2002; Bogdanović et al. 2018; Borisov et al. 2018, Mura et al. 2017; Vlacsekova, Mura, 2017).

It is important to focus on the nature of the relationship between creativity and management and does not privilege an 'artistic' or 'managerial' perspective. The disciplinary divide between creative programmes and management and the tension that arises between creative or creative endeavour and commercial constrains management in being able to realize creative endeavours, there is a lot that management can learn from the creative arts in terms of the way they manage their activities and the lessons that this might have for business (Lampel et al.2000; De Fillippi 1998; Sutton 2001; Tvaronavičienė, Razminienè 2017; Peterlin et al. 2018). 
It is thus important to frame an approach that does not favour one discipline over the other, but develops a common vocabulary privileging neither management nor creative endeavour.

\section{Factors influencing productivity of teamwork: theoretical aspects}

The considerable theoretical advancements have been made in linking contextual factors with intra-individual factors is Amabile's $(1988,1997)$ 'Componential Model of Organizational Innovation'. This identifies three intraindividual factors important for creativity: domain-relevant knowledge, creativity-relevant skills, and motivation. The Componential Model also describes characteristics of the work environment in an organization that impact on individual creativity via the above three intra-individual components: (1) organizational motivation to innovate; (2) resources and (3) management practices. According to Amabile's componential theory of creativity, creative work can be delineated into idea generation and problem solving. At each of these stages, teams are frequently used to tap into employee demographic diversity, cognitive styles and personality (Tagger 2002), divergent network ties (Perry-Smith, Shalley 2003), as well as functional heterogeneity.

Creative ideas need to be new and unique relative to others, and to what is currently available within the team or organization. Creative ideas have to be of value or useful to the team or organization. This focus on the mix of novelty and usefulness ensures that the definition of creativity is never static, but rather bounded within a social, cultural, or historical precedent (Perry-Smith, Shalley 2003). In the creative industries, where originality or the generation of something new is usually considered the currency of the realm (Florida 2002), there is continued pressure to look for ways to combine what already exists into something different or unique (Hargadon, Bechky 2006), to experiment with new, different, and existing ideas, as well to completely break from the known and venture into unknown territories.

Team creativity has been described as a collective phenomenon where members behaviorally, cognitively, and emotionally attempt new things, take novel approaches to their work; or generates products, processes, or procedures that are both novel and useful (Gilson, Shalley 2004). Team creativity can originate with the idea or suggestion of a single individual that is then developed, worked on, and elaborated upon by the team. In many teams there is a lead creator whose ideas are the seed for the projects that the team will subsequently develop.

Creativity can also emerge from the collective - an idea emanates from the unit and the unit as a team or as a collective works to refine and develop its ideas. Ideas also can be developed by subgroups, and then moved to the large groups who will further develop the idea and take the process forward. The work at Pixar can be considered as an exemplar in that small groups of individuals are encouraged to generate and refine ideas as well as give feedback and communicate with others inside and outside of the team. (Catmull, 2008). Creative individuals and artists are often labelled as eccentric, sensitive, self-confident, introvert, and intuitive (MacKinnon 1975) characteristics that are not count as good team members. Enterprises in the creative industries need to continually balance their need to tap into the creative potential of both individuals and the teams as a unit and therefor it becomes critically important that the environment be one where opinions and divergent thinking are encouraged (i.e., Pixar) and self-confidence and at times aggression is regarded as passion rather than the deviance. (Gilson 2015).

There is no doubt that some teams can excel in the production of creative ideas or products. Despite this fact, a great deal of research conducted in the area of group dynamics suggests that groups are often much less creative and productive than they are usually assumed (Rietzschel E. F et al. 2010), (De Dreu et al. 2008), (Camacho, Paulus 1995). 
In many cases a manager responsible for innovation development has limited resources to take care of all the factors influencing productivity of teamwork. The important question of how to manage creative teams to achieve a high productivity with limited resources and time arises in innovation management both from the theoretical and practical points of view. There is still no clarity which factors affecting productivity of teamwork are more important than others.

The study on group creativity as a multifaceted, multistage phenomenon (Rietzschel E. F et al., 2010) revealed that creativity is a multistage a process. The performance in one stage of the creative process does not automatically carry over into the next stages. Different stages of the creative process may be affected by completely different variables.

Many studies have been carried out in order to identify the factors that influence creativity in team (Rietzschel et al. 2010), (Amabile 2011), (De Dreu et al. 2008), (Stroebe, Diehl 1994), (Camacho, Paulus 1995). The fact that people produce fewer ideas when they work in a group as compared to when they work individually is partly due to some social factors, such as social loafing (Stroebe, Diehl 1994) and social inhibition (Camacho, Paulus 1995). The research on motivation of teams of knowledge workers (Amabile 2011) revealed two groups of factors "the catalyst" and "the nourishment" relevant to the progress of team performance. The study on the influence of hedonic tone (i.e., positive vs. negative moods) on creative performance (De Dreu et al. 2008) revealed that both positive and negative activating moods lead to higher creative performance than deactivating moods. There are studies which are focused on how to increase the innovation efficiency not at team level, but at meso or macro levels (Bae, Chang 2012).

\section{Empirical research methodology on the factors influencing productivity of teamwork}

Usually creative teams differ in terms of their composition, the task being carried out, and the resources available, etc. Very often neither the task assigned to the team, nor the composition of the team nor the time allotted to carrying out the tasks can be changed, or can be changed only insignificantly. It has been noticed that some teams can achieve better results even when they have the same resources, carrying out the same or similar task and having the same amount of time allotted to them as other teams. The urgent question of how to manage creative teams to achieve a high performance of the team arises in creative team management both from the theoretical and practical points of view.

The present investigation is aimed at establishing the factors that determine the high performance of creative teams. Having elucidated the major factors of organising teamwork that determine a high performing team, it is possible to focus attention on those factors and thus increase the efficiency of collective work. A questionnaire survey of team members, which they filled in upon completion of the task involving the relevant teamwork, was applied to an empirical investigation. The questionnaire was devised according to the factors that have an effect on a team established by Teresa Amabile (Amabile 2011). Teresa Amabile (Amabile 2011) divides the factors that influence teams into catalysing factors, which have an effect on the performance-progress of the team and supporting factors, which have an effect on inner work life. According to Amabile, the catalysing factors have an effect on the inner work life of a creator too. The group of catalysing factors is made up of the following: clear meaningful goals, autonomy/freedom, sufficiency of resources, help at work, learning from problems and achievements, an open flow of ideas, and sufficiency of time. The group of supporting factors consists of the following: respect and recognition, encouragement, emotional support, a feeling of belonging and friendship/a sense of community. 
The International Journal

ENTREPRENEURSHIP AND SUSTAINABILITY ISSUES

ISSN 2345-0282 (online) http://jssidoi.org/jesi/ 2018 Volume 6 Number 2 (December) http://doi.org/10.9770/jesi.2018.6.2(3)

In carrying out the survey of the teams, each member of the team was asked to evaluate the following factors: whether the task of the team was clear/interesting; whether personal tasks were clear/interesting; team/personal autonomy; team/personal time; team/personal knowledge; the leader's help; the team's openness to ideas; learning from experience; respect within the team; team unity; job satisfaction in teamwork; leadership assessment; evaluation of the results achieved. The 7-point Likert scale was used for the evaluation. The higher the value of the point was, the stronger the factor under assessment manifested itself in the opinion of the team member. A total of 487 team members from 113 teams in 8 countries were interviewed: in Denmark (22 members from 6 teams), in Italy (21 members from 9 teams), in Canada (131 members from 20 teams), in China (39 members from 7 teams), in Lithuania (161 members from 38 teams), in Poland (70 members from 19 teams) in France (23 members from 8 teams) and in Russia (20 members from 6 teams).

These countries were chosen seeking to ensure a cultural and geographical variety of creative teams (relatively large and small countries, countries of Western and Oriental culture, etc.). Student creative teams were studied, that is, these teams had to find/generate some creative solution. The team member being interviewed had to evaluate the factors that had an effect on the team and its performance. According to the evaluation of performance, three groups were distinguished: of high performance (6-7 points), of average performance (5 points) and of low performance (1-4 points). Further the evaluations of only high and low performance teams calculating the averages of the evaluation of the factors of high and low performance teams in different countries were considered and compared. Though the tasks assigned to the teams and the duration of performing them were different, the teams of the same country had the same task and the same time allotted to perform it, and the same resources, therefore calculating the averages of these countries and comparing them was meaningful.

\section{Evaluation of the performance factors of creative teams}

The average of the evaluation of the performance factors of creative teams of all the countries under study (Denmark, Italy, Canada, China, Poland, Lithuania, France, and Russia) shows that high performance teams valued (see Fig. 1) respect most in the team (6.30 points), team autonomy (6.16 points), the team's openness to ideas (6.13 points), and team unity (6.09 points). The criteria of whether the task was interesting and teamwork satisfaction were evaluated at 5.98 points (Figure 1). 
The International Journal

ENTREPRENEURSHIP AND SUSTAINABILITY ISSUES

ISSN 2345-0282 (online) http://jssidoi.org/jesi/

2018 Volume 6 Number 2 (December)

http://doi.org/10.9770/jesi.2018.6.2(3)

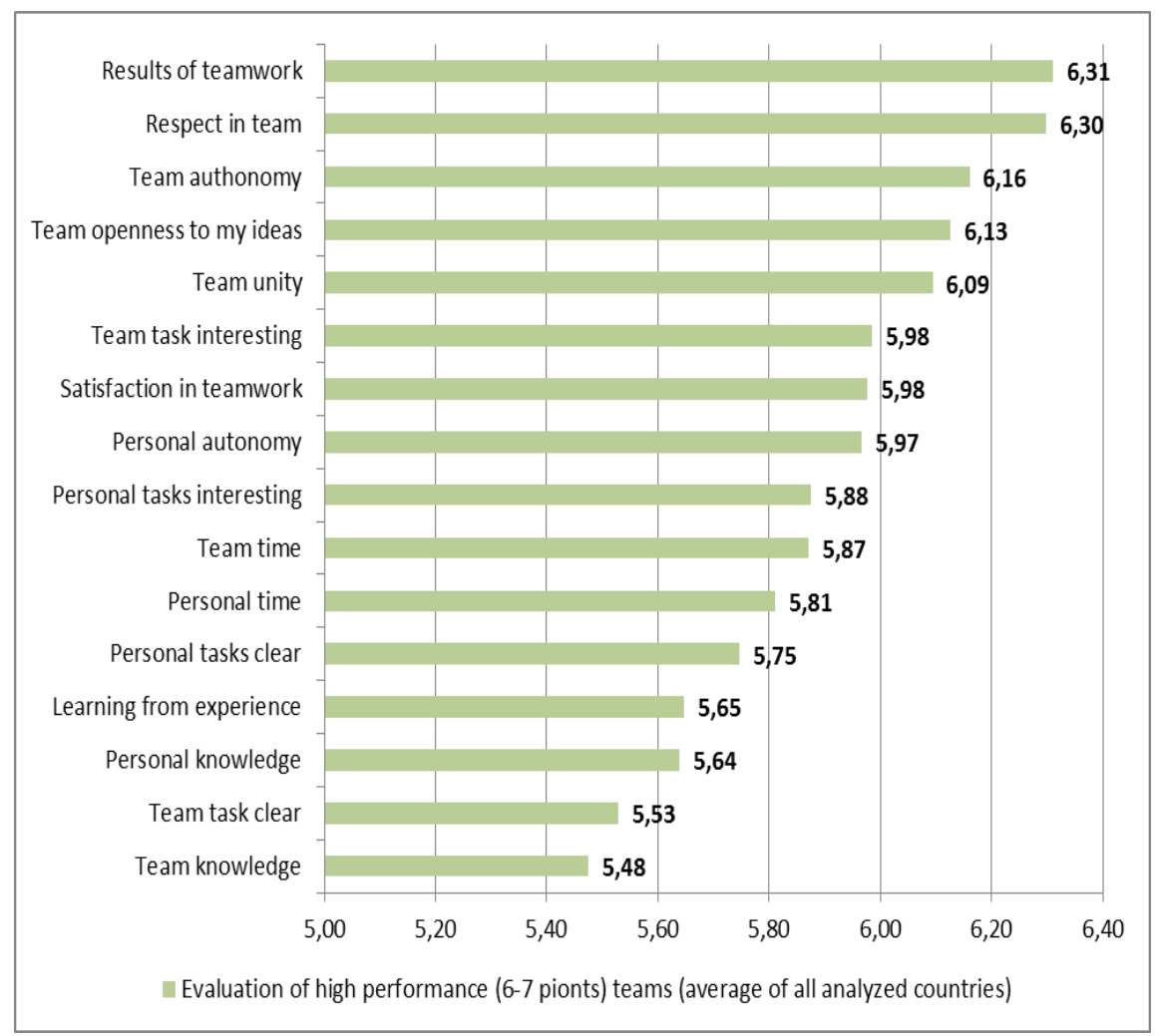

Fig. 1. Overall evaluation of the factors of high performance (6-7 points) teams

The average of all the evaluation of performance of creative teams of all the countries under study (Denmark, Italy, Canada, China, Poland, Lithuania, France, and Russia). It shows that low performance teams (see Fig. 2) gave the lowest valuation to whether the team task was interesting (3.91 point), the team's knowledge (4.03 points), learning from experience (4.04 points) and personal knowledge (4.19 points) (Figure 2). 


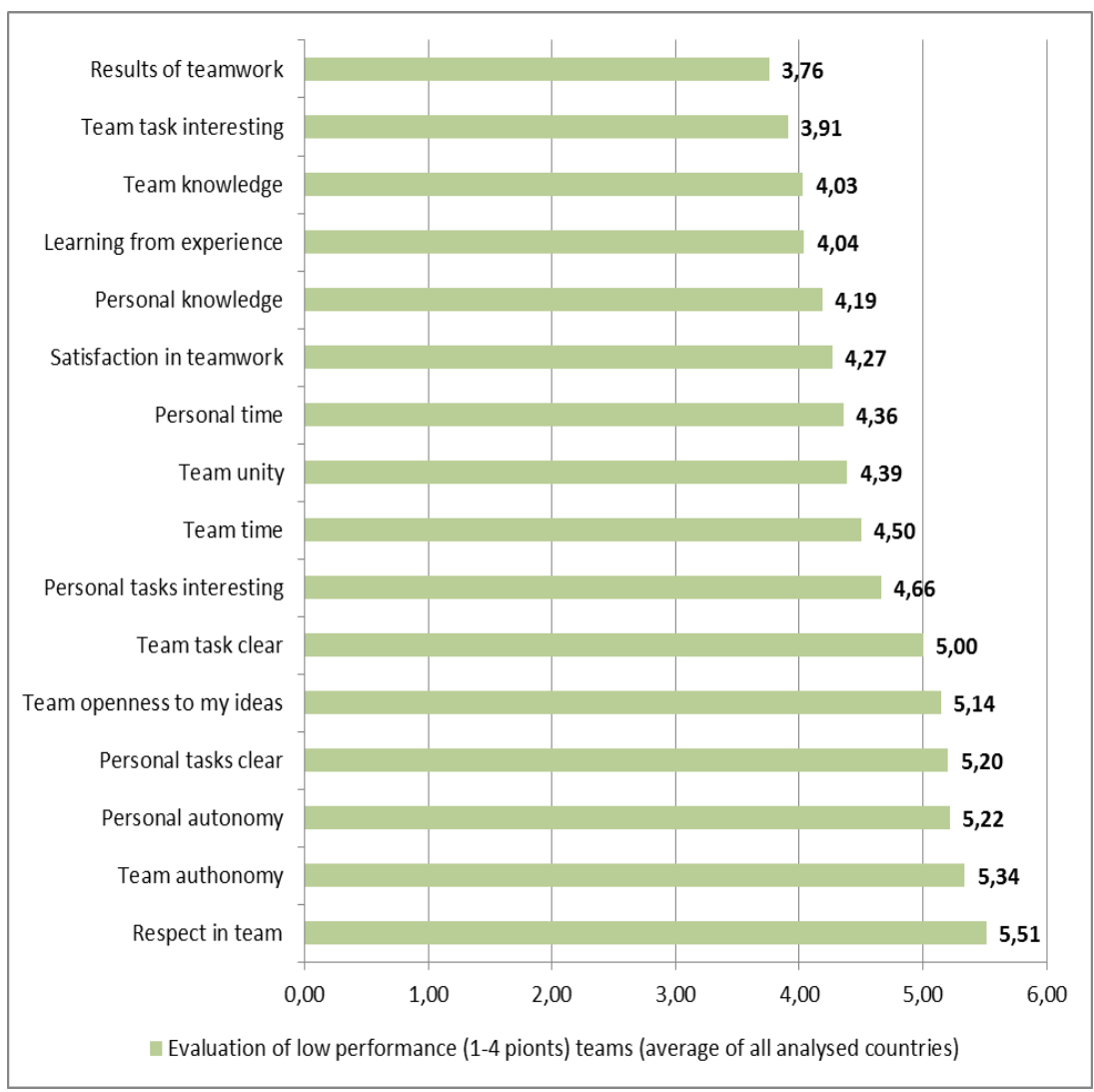

Fig. 2. Overall evaluation of low performance (1-4 points) teams

Low performance teams conditionally gave the highest valuation to respect in the team (5.51 points), team autonomy (5.34 points) and personal autonomy (5.22 points).

When comparing the differences in the evaluation of the factors of high and low performance teams, we see that high performance teams valued all the factors of the effectiveness on average at a higher level. The greatest differences are in the evaluation of whether the team task was interesting (difference of 2.08 points), teamwork satisfaction (difference of 1.71 point), and team unity (difference of 1.70 point) (see Fig. 3 ). 


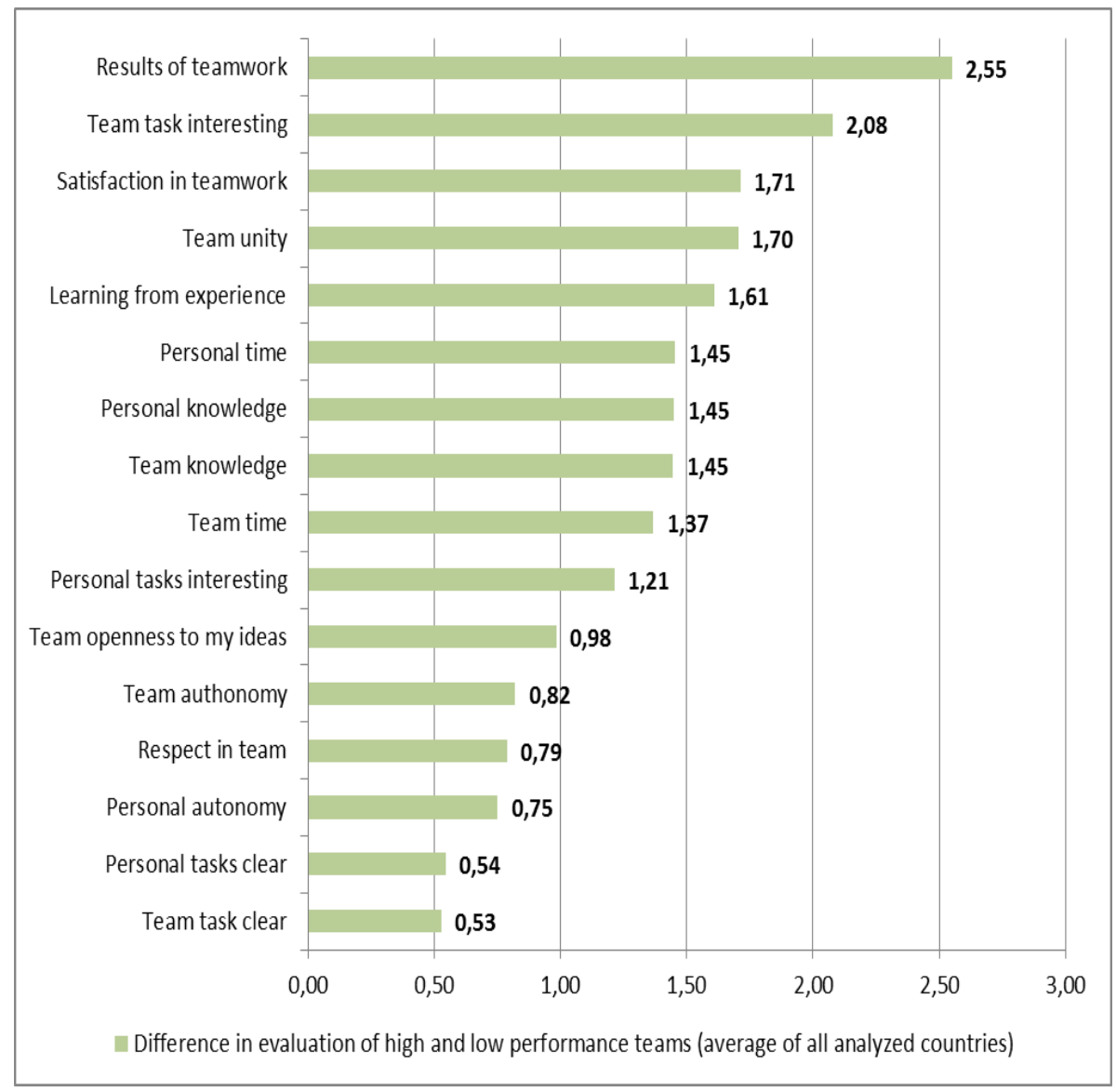

Fig. 3. Difference in evaluation high and low performance teams

The least differences between high and low performance teams are in the evaluation of whether the team task was clear (difference of 0.53 points), the evaluation of whether the personal task was clear (difference of 0.54 points), the evaluation of personal autonomy (difference of 0.75 points) and the evaluation of respect in the team (difference of 0.79 points).

\section{The hierarchy of factors influencing the teamwork productivity}

As it was already mentioned, according to Teresa Amabile (Amabile, 2011), knowledge team motivation factors can be divided into catalysing factors, which influence the performance-progress of the team and supportingnourishing factors, which have an impact on inner work life. Catalysing factors also influence the inner work life of the creator. The group of catalysing factors consists of the following: clear meaningful goals, autonomy/freedom, sufficient resources, help at work, learning from problems and achievements, an open flow of ideas, and sufficient amount of time. The group of nourishing factors consists of the following: help and recognition, incentive, emotional support, belonging and friendship.

Investigations carried out into 487 team members (113 teams) from 8 countries (Lithuania, Poland, Canada, China, France, Italy, Russia, and Denmark) showed that the team's members' satisfaction is directly related to the 
results achieved by the team). The conducted investigations confirm the so-called Progress Principle by Teresa Amabile, which states that progress achieved by the team has a positive impact on the creator's inner work life, and the creator's positive inner work life has a positive effect on the result/progress of the team. The conducted investigations supplement Teresa Amabile's Progress Principle in revealing the impact of both catalysing and supporting factors on the results of the team. The hierarchy of the significance of the factors is established on the basis of the impact of the factors on the team's result/progress. Two groups of factors i.e. basic micro factors and additional micro factors are identified: The basic micro factors are (see Fig. 4):

- an interesting team task;

- the team's openness to ideas;

- learning from experience;

- team autonomy;

- respect in the team;

- team unity.

The additional micro factors are:

- $\quad$ team task clear;

- $\quad$ team knowledge;

- $\quad$ team time available for the task;

- personal autonomy;

- $\quad$ personal knowledge;

- $\quad$ personal time available for the task;

- personal task clear.

In order to achieve a higher result/performance of a creative team the greatest attention must be devoted to the basic micro factors. A task should be interesting for the team. The team members should be open to the ideas and respect each other. For the high productive team a sufficient level of autonomy have to be granted. It includes financial, decision making, teamwork management and other autonomy. Management of the team also has to stimulate sense of team unity. It is also very important to establish Leaning from the experience/continuous improvement system in order to constantly analyze the performance and satisfaction of the team. Key performance and key satisfaction indicators have to be established as well as regular monitoring procedures. The above mentioned basic micro factors and additional micro factors could be used for development of key satisfaction indicators.

Our findings also revealed that result/performance of the team has direct impact on satisfaction of the team. High result/performance of the team stimulates better satisfaction of the team which could lead to the establishment of positive loop i.e. high result/performance - better satisfaction, better satisfaction - high result/performance. The opposite to the positive loop it could be a negative loop when poor result/performance could lead to dissatisfaction and then dissatisfaction lead to even worst result/per high result/performance of the team. 


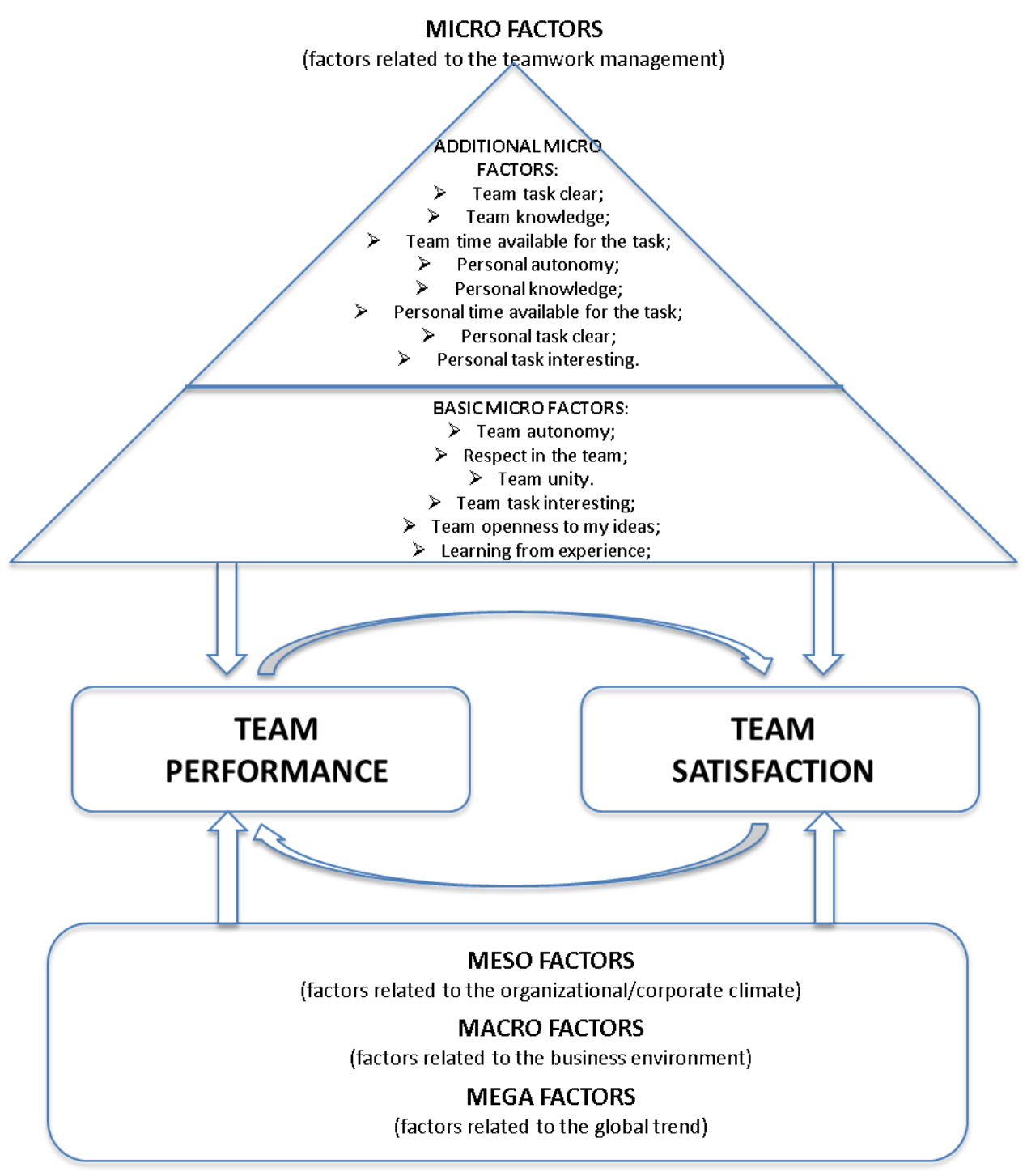

Fig.4. The hierarchy of factors influencing the teamwork productivity

Attention is to be paid to the fact that micro factors are not only factors which has impact to the performance/result of a team. Our research revealed that a team could achieve very different final result/performance with the same or very similar micro factors (task, time available, composition of the team and etc.). A poor performance of the team could be influenced by increase competition, negative political, economic, social or technological changes. This shows that not only micro but also other factors (mega, macro and meso) factors could have a big impact on the results/performace of the teams.

It means that in order to achieve high performance of the team meso, macro and mega factors should be taken into consideration. 


\section{Conclusions}

The research findings confirmed the so-called "Progress Principle" by Teresa Amabile (Amabile, 2011) in revealing the impact of both catalysing and nourishment factors on the results of the teams. The hierarchy of the significance of the factors influencing the productivity of teamwork is established.

The hierarchy factors influencing the productivity of teamwork consist of two groups of factors:

Basic micro factors. This group includes 6 factors (interesting team task, the team's openness to ideas, learning from experience, respect in the team, team unity and team autonomy). These factors are crucial for productivity and satisfaction of a team;

Additional micro factors. This group of factors includes such factors as time allocate to the team, team knowledge, team task, personal time of the team members, personal knowledge of the team members, personal autonomy, and clear and interesting personal tasks. These factors are important for productivity and satisfaction of a team.

The finding of the study shows that in order to achieve higher productivity of a creative team the greatest attention must be given to the factors of higher hierarchical level. Such focus would help to achieve not only higher productivity of teamwork, but would also increase the efficiency of innovation development process. The findings are relevant not only for creative industries, but also for innovation development in other sectors as the higher productivity of a creative team would affect the efficiency of innovation development in all sectors.

Despite the fact that all the analysed teams were given conditionally the same task, the same goal, same time and resources, some of the teams managed to achieve better results than others. This shows that not only micro factors had an influence of the productivity of the teams, but also external environmental (mega, macro and meso) factors had also an impact on the results of the teams. Mega, macro and meso factors can have a crucial impact on productivity of teamwork in creative industries, despite existence of all necessary positive micro factors. The influence of mega, macro and meso factors have to be additionally investigated.

Limitation of the study. The paper presents conclusions from students teams involved in development of creative projects, but not from the teams working in creative industries, assuming that factors of productivity in students teams involved in creative projects are similar to the teams working in creative projects in creative industries. To identify factors influencing productivity of teams working in creative industries are difficult due uniqueness of each projects (task, allocated resources, timing and etc.). These factors usually are out of direct control of the creative teams and are determined by meso, macro and mega factors (customers, CEOs, competitors, market and etc.) Research of students teams involved in development of creative projects allowed us to partially eliminate these factors and concentrate on the factors that are in direct control of creative teams. It implies that the presented research was conducted on closed to reality environment, but in order to verify the results, further research should be done in real environment i.e. by analysing teams in creative industries. 


\section{References}

Amabile, T M. \& Kramer, SJ. (2011). The power of small wins. Harvard Business Review, 89 (5), 70-80. https://hbr.org/2011/05/thepower-of-small-wins

Amabile, T M (1988) A model of organizational innovation. In B. M. Staw, L. L. Cummings (Eds.) Research in organizational behavior, 10, 123-167. https://www.hbs.edu/faculty/Pages/item.aspx?num=7441

Amabile, T M (1997) Motivating creativity in organizations. California Management Review, 40 (1), $22-26$. http://bear.warrington.ufl.edu/weitz/mar7786/articles/amabile\%20ccal\%20mgt\%20review.pd

Amabile, T M (1996) Creativity in Context. Boulder, CO: Westview. https://www.hbs.edu/faculty/Pages/item.aspx?num=268

Bae Y, Chang H (2012) Efficiency and effectiveness between open and closed innovation: empirical evidence in South Korean manufacturers. Technology Analysis \& Strategic Management, 24(10), 967-980. https://doi.org/10.1080/09537325.2012.724164

Bogdanović M, Vetráková M, Filip S (2018) Dark triad characteristics between economics \& business students in Croatia \& Slovakia: what can be expected from the future employees? Entrepreneurship and Sustainability Issues, 5(4), 967991. https://doi.org/10.9770/jesi.2018.5.4(19)

Borisov A, Narozhnaia D, Tarando E, Vorontsov A, Pruel N, Nikiforova O (2018) Destructive motivation of personnel: a case study of Russian commercial companies. Entrepreneurship and Sustainability Issues, 6(1), 253-267. https://doi.org/10.9770/jesi.2018.6.1(16)

Camacho, L M., Paulus, P B (1995) The role of social anxiousness in group brainstorming. Journal of Personality and Social Psychology. 68, 1071-1080 http://dx.doi.org/10.1037/0022-3514.68.6.1071

Catmull, E (2008) How Pixar Fosters Collective Creativity. Harvard Business Review. September 2008. https://hbr.org/2008/09/how-pixarfosters-collective-creativity

Caves, R E (2000) Creative Industries. Cambridge, MA: Harvard University press. https://www.crb.gov/proceedings/2006-3/riaa-ex-o148-dp-amended.pdf

Cox G (2005) Cox Review of Creativity in Business. Norwich: HMSO. https://www.researchgate.net/publication/261737931

Cronqvist, Lasse (2011) Tosmana: Tool for Small-N Analysis [Computer Programme], Version 1.3.2.0. Trier: University of Trier https://www.tosmana.net

De Dreu, C K W, Baas M., Nijstad, B A (2008) Hedonic tone and activation level in the mood-creativity link: Towards a dual pathway to creativity model. Journal of Personality and Social Psychology, 94, 739-756. https://doi.org/10.1037/0022-3514.94.5.739

DeFillippi, R. Arthur, M (1998) Paradox in project-based enterprise: the case of film making. California Management Review, 40(2), 12539. http://citeseerx.ist.psu.edu/viewdoc/download?doi=10.1.1.199.8422\&rep=rep1\&type=pdf

Diehl, M., Stroebe, W. (1987). Productivity loss in brainstorming groups: Toward the solution of a riddle. Journal of Personality and Social Psychology, 53, 497-509. http://dx.doi.org/10.1037/0022-3514.53.3.497

Eliashberg J, Elberse A, Leenders M (2006) The Motion Picture Industry: Critical Issues in Practice, Current Research and New Research Directions. Marketing Science, 25 (6), 638-661 http://www.people.hbs.edu/aelberse/publications/eliashberg_elberse_leenders_2006.pdf

Flew T (2004) Creativity, cultural studies and service industries. Communication and Critical/Cultural Studies, 1(2), 176-93. https://doi.org/10.1080/14791420410001685377

Florida R. (2002) The Rise of the Creative Class: And How Its' Transforming Work, Leisure, Community and Everyday Life. NY: Basic Books.

Gabriel Y (2002) On the paragramatic uses of organizational theory. Organization Studies, 23(1), 133-51. 
The International Journal

ENTREPRENEURSHIP AND SUSTAINABILITY ISSUES

ISSN 2345-0282 (online) http://jssidoi.org/jesi/

2018 Volume 6 Number 2 (December)

http://doi.org/10.9770/jesi.2018.6.2(3)

Garnham N (2005) From cultural to creative industries. International Journal of Cultural Policy, 11(10), 15-29. https://doi.org/10.1080/10286630500067606

Gilson L L (2015) Creativity in Teams: Processes and Outcomes in Creative Industries. In Jones, C., Lorenzen, M., Sapsed, J. (eds.) Oxford Handbook of Creative Industries. Oxford UP. P. 50-74.

Gilson L L, Shalley C.E (2004) A little creativity goes a long way: an examination of team's engagement in creative processes. Journal of Management, 30:453-470. https://doi.org/10.1016/j.jm.2003.07.001

Goncalo J, Neale M, Mannix E (2009) Creativity In Groups, Bingley, UK: Emerald, eBook Academic Collection (EBSCOhost),

Hargadon, A., Bekchky, B. (2006). When collections of creatives become creative collective - a field study of problem solving at work at work. Organization Science. 17:484-500. https://10.1287/orsc.1060.0200

Hesmondhalgh D (2007) The Cultural Industries. London: Sage. file:///C:/Users/Manuela/Downloads/osvrt03 hesmondhalgh.pdf

Howkins J (2001) The Creative Economy. London: Penguin. https://www.penguin.co.uk/books/196214/the-creativeeconomy/9780141977034.html

Jeffcutt P, Pick J, Protherough R (2000) Culture and industry: exploring the debate. Studies in Cultures, Organizations and Society, 6,12943

Lampel J, Lant T, Shamsie J (2000) Balancing act: learning from organizing practices in cultural industries. Organization Science, 11(3), 263-9. http://www.creativetrust.ca/wp-content/uploads/2010/12/Learning-from-Practices-in-Cult-Industries.pd

Leadbeater C, Oakley K (1999) The Independents: Britain’s New Cultural Entrepreneurs. London: Demos.

MacKinnon D.W (1975) IPAR's contribution to the conceptualization and study of creativity. In I.Taylor and J.Getzels (eds.) Perspectives in creativity. Chicago: Aldine. p. 60-89.

Mitkus, T., \& Maditinos, D. (2017). Analysis of state aid policy to stimulate innovation and internationalization in Lithuanian animation industry. Oeconomia Copernicana, 8(3), 433-446. https://doi.org/10.24136/oc.v8i3.27

Mura L, Ključnikov A, Tvaronavičienè T, Androniceanu A 2017. Development Trends in Human Resource Management in Small and Medium Enterprises in the Visegrad Group, Acta Polytechnica Hungarica 14(7), 105-122. http://www.uni-obuda.hu/journal/Issue78.htm

Perreti F, Negro G (2007) Mixing genres and matching people: a study in innovation and team composition in Hollywood. Journal of organizational behavior, 28, 563-586. https://doi.org/10.1002/job.464

Perry-Smith J.E, Shalley C.E (2003) The social side of creativity: A static and dynamic social network perspective. Academy of Management Review, 28, 89-106. http://dx.doi.org/10.2307/30040691

Pratt A (2005) Cultural industries and public policy: an oxymoron? International Journal of Cultural Policy, 11(1), 31-44. http://dx.doi.org/10.1080/10286630500067739

Peterlin J, Dimovski V, Tvaronavičienė M, Grah B, Kaklauskas A (2018) The strategic process of developing social aspects of sustainability through the vision reflection in business education, Technological and Economic Development of Economy, 24(4), 17181736 https://doi.org/10.3846/tede.2018.5198

Rietzschel E, Nijstad B, \& Stroebe W (2010) The selection of creative ideas after individual idea generation: Choosing between creativity and impact, British Journal Of Psychology, 101, 1, pp. 47-68. http://dx.doi.org/10.1348/000712609X414204

Stroebe W., \& Diehl M (1994) Why groups are less effective than their members: On productivity losses in idea-generating groups. In: W. Stroebe \& M. Hewstone (Eds), European review of social psychology, 5, 271-303). London, UK: Wiley. https://doi.org/10.1080/14792779543000084

Sutton R I (2001) The weird rules of creativity. Harvard Business Review, 79(8), 96-103. 
The International Journal
ENTREPRENEURSHIP AND SUSTAINABILITY ISSUES

ISSN 2345-0282 (online) http://jssidoi.org/jesi/

2018 Volume 6 Number 2 (December)

http://doi.org/10.9770/jesi.2018.6.2(3)

Stepaniuk K (2018) Visualization of expressing culinary experience in social network, memetic approach. Entrepreneurship and Sustainability Issues, 5(3), 693-702. https://doi.org/10.9770/jesi.2018.5.3(21)

Strielkowski W (2018) Heritage, screen and literary tourism. Tourism Management, 69, 537-537. https://doi.org/10.1016/j.tourman.2018.07.004

Tvaronavičienė M., Razminienė K. (2017) Towards competitive regional development through clusters: approaches to their performance evaluation. Journal of Competitiveness, 9(4), 133 - 147. https://doi.org/10.7441/joc.2017.04.09

Wasko J (2003) How Hollywood works, London, Sage. http://dx.doi.org/10.4135/9781446220214

Vlacsekova, D., \& Mura, L. (2017). Effect of motivational tools on employee satisfaction in small and medium enterprises. Oeconomia Copernicana, 8(1), 111-130. https://doi.org/10.24136/oc.v8i1.8

Dr. Jurate ČERNEVIČİ̄TĖ is a professor in Vilnius Academy of Arts, Department UNESCO Culture Management and Cultural Policy. She is currently working on creative industries spill-over effect on Lithuanian regions and small towns - Alytus and Utena - sustainable development. Research interest: creative industries impact on sustainable development of regions; creativity management; system innovation development.

ORCID ID: orcid.org/0000-0001-5545-1667

Dr. Rolandas STRAZDAS is a professor at the Department of Creative Communications of Vilnius Gediminas Technical University (VGTU), Lithuania. He is, project manager, researcher, lecturer, and consultant. Research interests incorporate innovation management, business process analysis, business models, creative industries, manufacturing process improvements.

ORCID ID: orcid.org/0000-0002-7163-3337

Copyright (C 2018 by author(s) and VsI Entrepreneurship and Sustainability Center

This work is licensed under the Creative Commons Attribution International License (CC BY).

http://creativecommons.org/licenses/by/4.0/

(c) (i) Open Access 